\title{
THE ANTI-AUTHORITARIAN ROLE OF DYSTOPIAS: REFLECTIONS ON ÉRICO VERÍSSIMO'S NOVEL INCIDENT IN ANTARES ${ }^{1}$
}

\section{THE ANTI-AUTHORITARIAN ROLE OF DYSTOPIAS: REFLECTIONS ON ÉRICO VERÍSSIMO'S NOVEL INCIDENT IN ANTARES}

\author{
Fabiana Maria Baptista ${ }^{2}$ \\ Guilherme Prado Roitberg ${ }^{3}$
}

\begin{abstract}
The aim of this article is to analyze the relevance of dystopias in the critique to authoritarianism present in the novel Incident in Antares written by Érico Veríssimo. After presenting the main characteristics of utopian thought and dystopia as a literary genre, we investigate how Veríssimo denounced through his dystopian society the deepest contradictions of a country historically plagued by coups d'état and military dictatorships. The article also aims to demonstrate how prevailing Veríssimo's criticism is, especially regarding to the permanence of authoritarian thought, social inequalities and violations of human rights in Brazil.
\end{abstract}

Key-words: Érico Veríssimo; Incident in Antares; literary dystopias; anti-authoritarianism.

Resumo: O objetivo do presente trabalho consiste em analisar a partir do romance Incidente em Antares de Érico Veríssimo a relevância das distopias na crítica ao autoritarismo. Após apresentarmos as principais características do pensamento utópico e da distopia enquanto gênero literário, investigamos de que maneira Veríssimo denunciou através de sua sociedade distópica as mais profundas contradições de um país historicamente assolado por golpes de Estado e ditaduras militares. O trabalho almeja demonstrar, por fim, a atualidade da crítica de Veríssimo frente à permanência do pensamento autoritário, das desigualdades sociais e das violações aos direitos humanos no Brasil.

Palavra-chave: Érico Verísimo; Incidente em Antares; distopias literárias; antiautoritarismo.

\footnotetext{
1 With no intention to depreciate Veríssimo's rich text in Portuguese, we have chosen to keep the text entirely in English, in order to extend the scope of the work and the criticism present in the book Incident in Antares to readers of other countries. The direct and indirect citations were freely translated from 2006 Brazilian edition. By analyzing directly several parts of the book, we have chosen not to use the original Portuguese passages in footnotes, given the volume of pages and the limits of our work.

2 Mestre em Educação pela Universidade Estadual Paulista Julio de Mesquita Filho, campus de Rio Claro. Graduada em Inglês pela Universidade Metodista de Piracicaba (2007) com especialização em Sociologia (2015) e em Língua Inglesa/ Tradução (2012).E-mail: fabianamariabap@gmail.com

3 Doutorando em Educação pela Universidade Federal de São Carlos (UFSCar). Mestre em Educação (2018) e graduado em História (2010) pela Universidade Estadual Paulista Júlio de Mesquita Filho com especialização em Filosofia (2015). E-mail: guilhermeroitberg@gmail.com
} 


\section{INTRODUCTION}

This article proposes to analyze the role of dystopian literature in criticizing the most diverse forms of authoritarianism, based on the society created by the writer Érico Veríssimo (1905-1975) in his book Incident in Antares (1971). From a historical and dialectical perspective, it is possible to investigate the critical potential of dystopian thought in the creation of spaces in which the magical realism translates the transgression inside highly restrictive societies. From the book written by the philosopher Plato (428/427-348/347 BC), The Republic to the celebrated Utopia by Thomas More (1478-1535), literature has been a fertile field for the construction of utopian societies capable of criticize social problems in the most diverse historical contexts, as well as conceive the creation of a new world based on new social arrangements, as we will see later.

For utopian scholars such as Coelho Netto (1985, pp. 14-16), the utopian thought is inherent in man, being a constituent part of all historical societies. However, as a concept, the term arises only in the 16th century with Thomas More: ou-topos, the no place, the nowhere. More's choice of the name, is emblematic, showing that, as in England of his time, that thought appears as something subversive, capable of challenging the socially established order. Political utopias allow the anticipation of the future "as projection of a present from what exists in this time and it is capable of being transformed" and "improved," thus comprising a "demanding imagination," which "has always been present in human societies", driving forces for revolutions, discoveries and inventions. In this way, utopian societies would not be "a simple abstract utopian dream", nor future views and prophecies, but rather the result of a "concrete utopian imagination", capable of influencing present time from the projection of the future (COELHO NETTO, 1985, pp.12-13).

\section{“THE DREAM OF REASON PRODUCES MONSTERS”: BETWEEN UTOPIAS AND DISTOPIAS}

According to Rodrigues (2010, pp.98-99), the magical realism, is a literary genre that allowed the elaboration of dystopian societies and it appeared paradoxically in the 18th century, precisely in the Century of Lights. That moment, marked by the affirmation of empiricism and the rejection of metaphysics, led to the great movement of rationalization that started the period of Modernity. However, the "rational and logical explanation of the world and of History," which created "social systems and criticisms," was unable to account for all the uniqueness and "complexity of the individuation process." If, in one way, rationality still faces limits imposed by man himself, on the other hand, the "community imaginary never ceases to be nourished by all sorts of esotericisms, necromancies" and other elements that escape "the proposed rationality".

For the theorists and critics of the Frankfurt School, especially Theodor Adorno (1903-1969) and Max Horkheimer (1895-1973), this instrumental rationality, opposing the Illuminist utopia, not only was incapable of emancipating man, as allowed the development of a logic of domination, of a subjectivity based on conformism, fetishism, alienation, reification and resignation (ADORNO, 2010, pp. 33-36). Taken to the extreme by the totali- 
tarian regimes of the first half of the $20^{\text {th }}$ century, this semi-formation, based on bourgeois coldness, violence, insensitivity and indifference to pain, contributed to the strengthening and acceptance of the barbarism that had in Auschwitz its peak, but not its end (ADORNO, 2000, pp. 127-129). In this context, dystopias appear as cathartic possibilities of criticism and denunciation of totalitarian reason, as shown by Pinto (2009, pp. 14-15):

Generally associated with "science fiction," dystopias are "the description of a place outside History, where social and class tensions are conciliated by violence or social control." [...] As the name itself says, dystopia is the opposite of utopia, or a "negative utopia." Utopias have emerged as an inverted image of the real as a kind of positive counterpart of critical reason: if one of the most persistent philosophical attitudes over time is anti-dogmatism and denunciation of a society built on a system of mystifications (myth, religion, ideology), utopia would be the world possible from the moment all these beliefs had been overcome. It highlights one of the characteristics of utopias: they seem unreal because they are too rational and contrast with the prevailing irrationality of social relations. Utopias are constituted by idyllic nations, in which solidary and just men maintain relations of cordiality amidst a bountiful and domesticated nature, which serves as the barn and garden of humanity. Utopias are, so to speak, the dream of reason, as well as a vulgarization of humanism - and that is why the great Western utopias are understood between the rebirth and the end of the 19th century. In an anti-humanist century such as the one we have just gone through, however, reason has ceased to be the antipode of unreason, mythology, and religion, to itself become an outgrowth of this dominating fury. "Clarification, that is, instrumental reason, is the radicalization of mythic anguish," wrote Adorno and Horkheimer, "and the literary imagination of the 19th century was prodigal in creating fictitious societies in which rationality becomes an end in itself: abstract, mechanical, reducing the existing one to a utensil, alienating the consciousness in the assembly line and producing massacres with industrial planning. In the 20th century, as in Goya's famous painting, the dream of reason produces monsters. Or, in other words, dystopias.

The painting mentioned by Pinto is one of the most emblematic images of the Spanish painter Francisco de Goya (1746-1828), especially when dealing with the topic of dystopias:

\section{[LOCAL ONDE A ILUSTRAÇÃO SERÁ INSERIDA, DE ACORDO COM O ITEM 8 DAS DIRETRIZES PARA AUTORES]}

The series Los caprichos criticized the behavior of the Spanish nobility and the clergy of the late 18th century. Through his work, Goya criticized religious fanaticism, inquisition, unjust laws and advocated a new system of education for children. Considered as a precursor of modern art, Goya influenced later artists and movements such as Impressionism, French Romanticism, German Expressionism and Surrealism (GUDIOL, 2008, p.20). In the 
mentioned painting, as the man falls asleep, bats and wild birds fly over his head completely defenseless, just like in a nightmare that, even for a few seconds, can tormente a whole night's sleep. In the words of the French poet Charles Baudelaire (1821-1867), Caprichos by Goya represents "the watercolor of civilization", where "light and darkness, reason and unreason, face all these grotesque horrors" (BAUDELAIRE, 1982, pp.310-311).

By bringing into the discussion of dystopias the image of Goya through a dialectical point of view, we consider that the utopian imagination is capable to produce both the most complex and liberating societies (utopian dreams), and the most totalitarian of political regimes (the dystopian nightmares). From the historical perspective, we observe that the domain of instrumental rationality in contemporaneity produced, as the Caprichos by Goya shows, an infinity of "monsters" such as xenophobia, neocolonialism, world wars, holocaust, racism, totalitarian regimes, among others. For this reason, it is precisely in the denunciation of barbarism that the cathartic, critical and formative potential of literary dystopias is found.

This "hidden face" of utopias allows us to affirm that "not everything, in its domains, is this supposed land of honey and wine" (COELHO NETTO, 1985, p.44). Literary dystopias (also called anti-utopias or negative utopias) constitute utopian societies constructed not as a model to be followed but as a cathartic critique of the harsh realities experienced by their authors in their respective historical contexts. As Coelho Netto points out (1985, p.35), "not everything proposed by the utopian imagination ends up favoring the development of a better life", which is why, considering dystopian societies as a possible reality, we ask ourselves how to prevent them from materializing.

\section{INCIDENT IN ANTARES: AN ANTI-AUTHORITARIAN PORTRAIT OF BRAZIL IN ÉRICO VERÍSSIMO DISTOPIC NOVEL}

In the book Incident in Antares, published in 1971 during the military dictatorship in Brazil, Érico Veríssimo masterfully addressed with his magical realism the political events that marked the History of the country. The author starts presenting a pre-history, in which he discusses the archaeological findings in Antares, a Brazilian city located in the state of Rio Grande do Sul, border between Brazil and Argentina. The book goes through troubled periods, among the 1930 Revolution that marks the rise of Getúlio Vargas (1882-1954) in politics, the coup and dictatorship of Estado Novo (1937-1945), the fall of Vargas (1945), his return to politics (1951) and his suicide (1954), as well as the populist republic of Juscelino Kubitschek (1902-1976) the government of Jânio Quadros (1917-1992), including his resignation in 1961 and the government of João Goulart (1919-1976), ended by the military coup in 1964.

Founded in 1853, the city of Antares was historically dominated by caudillos, living under the power struggle between the traditional Campolargo and Vacariano families, that seek to maintain their privileges through the political support of influential figures including governors and the president Getúlio Vargas (SANTOS, 2014, p.357). The incident that gives name to the book occurs on a Friday, December 13th, 1963, months before the coup that would oust President João Goulart and put the military in power for more than two 
decades. In the middle of a general strike in the city, which also reaches the category of gravediggers, seven dead unburied decide to fight for the right to be buried with dignity. Otherwise, they would gather in the bandstand of the central square and putrefy the air of the quiet city in the worst possible way. But before doing that, they would settle accounts with relatives, politicians, local authorities and other inhabitants of the city, exposing the contradictions of that corrupt society, which in many respects constituted itself as a great portrait of Brazilian society (VERÍSSIMO, 2006).

One of the deceased protestors was the alcoholic known as Pudim de Cahaça, dead poisoned by his wife, who was tired of his abusive behavior under the influence of drunkenness. Quitéria Campolargo, a matriarch who was part of one of the most traditional families in Antares, whose children fought for her inheritance, even before her corpse has cooled. João Paz, a young worker tortured by the police, but whose obituary registered "natural death due to pulmonary embolism", in a false document given by the delegate Inocêncio Pigarço. Professor Menandro Olinda, a gifted musician who committed suicide due to a severe depression and whose hands "froze" during his main performance due to his greatest childhood trauma: being caught by his fervent catholic mother while masturbating, hearing her cries that recriminating him during the first orgasm of his puberty. The prostitute Erotildes, who was morally and physically abused through her life by her clients, a victim of tuberculosis who was not treated in time thanks to the neglected health system. The militant anarchist Jose Ruiz, better known as Barcelona, a critic of capitalism and the individualistic and hypocritical lifestyle that hung over the ruling classes of the city. And finally, Cícero Branco, an influential lawyer and spokesman for the deceased: "who are now his witnesses to prosecution," exposing "the political and social ills of Antares" and "the moral rot that surrounds the main figures of the city," among them "the delegate and the mayor" (SANTOS, 2014, p.358; VERÍSSIMO, 2006).

Veríssimo attacks social inequalities, political corruption, and the mechanisms used by rulers to control popular demonstrations and revolts. In this sense, populism, laborism and the paternalistic profile of President Getúlio Vargas (1882-1954) are described through the figure of a woman called Acacia, a black maid who works in the office of the mayor of the city and who, at the height of her syncretism, venerated the "father of the poor" who "left life to enter History" as a kind of divinity even after his death. Faced with the aftermath of the funeral incident, the maid kneeled before the image of the "father of the poor", recited prayers and asked for protection for the city. Acacia then rises, groaning, and suddenly it occurs her to ask her "saint" for more, saying: "My gain here is not enough, and I work very hard, my president. Tell these people to pay me more. Amen!” (VERÍSSIMO, 2006, p.309).

Describing the context of the general strikes that occurred during the government of João Goulart (1961-1964), Veríssimo uses the figure of the influential colonel Tibério Vacariano (considered as the "owner" of Antares) to delineate the conservative reaction to labor policy and popular demonstrations calling for grassroots reforms and better living conditions for the working class (FAUSTO, 2008, pp.447-450). Many aspects of this authoritarian mentality and against social reforms are clear when Colonel Vacariano makes a connection with the governor of Rio Grande do Sul in an attempt to warn of the danger of the general strike that was about to take place in his small city: 
- It's the governor. So who's talking?

- Colonel Tibério Vacariano, from Antares. Sorry to keep you out of bed at this time, Governor, but the situation is very serious.

"What's the matter, Colonel?"

- Today at noon will be declared a general strike in Antares: industry, commerce, transport, electric power, services ... everything! The city will stop completely. [...] We are facing a calamity! Have you ever imagined a city without electricity, without water, without transportation? General strike!

- Yeah. I'm sorry.

"We must act immediately.

- How? Our Constitution recognizes the right of workers to strike.

"But this is no longer a strike but a principle of revolution, part of a leftist political conspiracy to seize power by force. [...]

"There is nothing my government can do within the law.

"Then make it outside the law."

- Hello? Speak up, colonel.

"To the hell with the legality!" Tibério shouted. "Send troops from the Military Brigade to Antares, and force these useless people back to work." The increase they ask for is absurd. The strike is of the workers of the local industries. The others only sympathized with them. Things that the bosses of P.T.B ${ }^{4}$. and the communes put inside the head of the workers.

"Colonel, you forgot we're in a democracy.

"Democracy, my ass, Governor!" What we have in Brazil is a "shitcracy".

- Hello?! The call is terrible.

"I told you we're in a shitcracy, understand?"

A silence is heard.

"You're very nervous, Colonel," came the voice again. - The federal government is a labor party. We are a minority.

- Minority my ass! What we lack is cojones, as the Castilians would say.

- Easy, my friend. Things can be solved from time to time within the law. I promise to talk to the Minister of Labor and ...

"The situation is no longer for talks, but for action. Do you want me to speak frankly? It was time for the National Army to step in, to exert power in the name of the people, of general tranquility and justice. Brazil at the moment is a train without brakes that rushes at full speed towards the abyss. And the worst is that the engineer and the stoker are crazy!

There was a silence, a distant throttle. At last the governor's voice became clearer: "There are certain matters, Colonel, that we cannot handle by telephone." Have a good day! (VERÍSSIMO, 2006, pp.201-203).

4 The Brazilian Labor Party is a political party in Brazil founded in 1945. 
Authoritarian thought and the dangers of totalitarianism are also denounced by Father Pedro Paulo, labeled by the ruling class as "communist." In one of his conversations with Father Gerôncio, Pedro Paulo clarified that "communist is the pseudonym that conservatives, conformists and nostalgists of fascism created to designate" in a simplistic way "any person who cries out and fights for social justice." "On the other hand," continues Pedro Paulo, "we are not unaware that in U.S.S.R. there is no freedom of criticism or expression" and that "a writer can be sentenced to three or five years of forced labor in Siberia" for writing "poems, articles or novels that contradict or simply do not follow the political line of the single party "(VERÍSSIMO, 2006, p.390).

Pedro Paulo also announced the tortures and arbitrariness committed by the police officer Inocêncio Pigarço, telling his colleague Gerôncio that "none of us ignores the crimes of the police chief and his torture specialists", accusing the citizens of Antares of closing "the eyes and mouth for comfort, indifference or cowardice" (VERÍSSIMO, 2006, p.390). When Father Paulo was preparing Rita, João Paz's widow for the first meeting with her husband after his death, - he who had been accused of communism and killed under police torture - the Father had said in his quiet voice: "He was tortured barbarously. His face is almost unrecognizable. One arm and one leg broken". Before leaving, realizing that the widow had been shaken both by her husband's return as a corpse and by her pregnancy, Father Paulo asked Rita to be strong, to maintain her faith in God and to prepare herself for the worst, since João Paz's body was already in a state of decomposition (VERÍSSIMO, 2006, p.302).

After Rita's sad, fetid and emotional encounter with João Paz's unburied remains, Érico Veríssimo uses the widow's voice to denounce the continuation of torture by the security forces against the communist threat represented by the family and the companions of the assassinated worker in similar scenes used during the period of dictatorship of Estado Novo (1937-1945), of military dictatorship (1964-1985), as well as in the arbitrary actions of the authorities that continue to occur in the current democratic period:

The morning they arrested you... they took me too, they threw me into a room without windows... completely dark... and there they left me a whole day, a whole night... Then they dragged me to another room, made me sit in a chair... I think there were many men, I could not see right because of that strong light in my eyes... They wanted to know the names of the "other ten" that you (they said) you were the boss... [...] But they did not believe me. They repeated the question. I swore by God that I did not know. And then those animals threatened to torture me... putting needles under my nails... One of them went so far and said that if I did not confess, they would take me naked to the soldiers of the guard... At a certain point one of them shouted, "If you do not confess we'll step on your belly, your bitch, and kill your son...” And then... I... I confessed! [...] Forgive me, Johnny... I was terrified. I thought about my son and I started to say names... the first ones that came into my head... names of our comrades... [...] I could say that it was only thinking about my son's life that I weakened. No. It was also thinking of my own flesh. I cannot stand physical suffering. I confessed because I'm a coward. After they released me, I heard that all the people I had denounced were arrested. I spent hours alone there in that chair, thinking about them, how they might be 
suffering because of me. If I did not kill myself... after all this and after they told me about your death... if I did not kill myself it was still because I am a coward (VERISIMO, 2006, pp. 306-307).

The scenes unfold from the stories of the characters, who gradually settle accounts or say goodbye to friends and family. Two notable excerpts deserve to be mentioned: the prostitute Erotildes meeting with her friend Rosinha and the sad scene of the trauma and the public embarrassment that contributed to aggravate the depression that led to the suicide of the teacher and musician Menandro Olinda. In the first case, Veríssimo uses the figure of the deceased prostitute to send light on the conditions of oppression and exploitation experienced by many women in similar cases. This lady, from 1925 to 1945, "by her grace and beauty" was one of the "most famous prostitutes in Antares", the "most sought female of Venusta brothel, the most expensive meat of that perfumed human butcher" (VERÍSSIMO, 2006, p.245). Among the seven deceased people, she was the one who had the "most cadaverous aspect": "the skin tightened on the bruised bones of her face" was "like a livid silk paper, through which one can almost see the skull" (VERÍSSIMO, 2006, p.261). At the moment of meeting with her friend Rosinha (who also worked as a prostitute), the description takes us to a tiny cubicle where the friend housed other prostitutes (including Erotildes, when she was alive):

\footnotetext{
Rosinha rented them the cubicle without ignoring the "girls" profession. But she imposed a rigid condition: "Do not bring males into the house, or else I'll send you away!" So they had to walk the streets hunting men, and when they could catch some, they would make love with them on land (and how often they had lain naked or half-naked on nettles or thorny plants!) or rushed up, in some corner of the wall, in deserted streets (VERÍSSIMO, 2006, p.291).
}

When she arrived with her corpse already in an advanced state of putrefaction, Erotildes is welcomed with much affection in that stuffy and tight room, even with its smell of rotten meat impregnating all possible spaces. The dialogue that follows, of indescribable depth and sadness, shows the friendship and companionship between the two women who, for many years, walked and stood side by side among aggressions, insults, acts of physical and moral violence, and social exclusion, so common among women who work as prostitutes in several countries of the world:

- How are you?

- More or less. And you?

- Dead. [...] How's business?

- Very bad. Getting worse. I always say: what is missing in Antares is a good military garrison.

"Don't you have any reliable friends?"

- Me? At this age? I thank when I get a man for a night. I make a misery and I do not get paid sometimes. You know how it is. No one wants to pay in advance. 
Rosinha lowers her head and says:

"Last night some boys grabbed me and led me to a vacant lot. About five or six... First they took off all my clothes, they tore an almost new dress. They knocked me down, put themselves in me, there was no crap they did not do to me. Then they left laughing and did not give me a measly penny.

"Known guys?"

"Some of them I believe I know by sight. Boys of good families.

"Sometimes they're the worst."

"But I do not know why they did that with me!" They did not have to cling to my nails, to mistreat me. If they said they had no money, I would give it away for free. But no! They looked like animals. Instead of coming from one to one, they came from two and even three. Pigs!

Erotildes gazes her friend with her gelatinous eyes and says softly:

"I tell you, I'm glad I'm dead. We are free forever from all these sorrows and shame.

"I've thought about dying." In taking poison. But I did not have the courage...

"It's a sin to commit suicide." You go to hell.

"But isn't hell right here?"

Suddenly Rosinha starts to cry. Erotildes raises her hand as if to stroke her friend's head, but she hesitates to touch her.

"It's nothing," she murmurs. "There is no good thing that will always last, or a bad thing that will never end, as my late mother would say.

Erotildes picks up the vaporizer and sprinkles her own perfume face. Then she says:

"Well, I've seen you. I still have almost three hours to spare. I think I'm going to see Sister Bonifácia, that nurse who was so kind to me when I was in the hospital. Goodbye, Rosinha, God help you!

She walks to the door.

- Erotildes? Have you seen God? The dead one returns:

- Not yet. I'm just going to see Him when I'm buried as a Christian.

Rosinha wipes the tears from her face with her fingertips.

- I'm going to ask you a favor...

- Which is?

- Tell God to give me a good death, since He did not give me a good life (VERÍSSIMO, 2006, pp.293-295)

The description of the aggression suffered by Rosinha reflects the situation of the historical violence suffered by prostitutes in Brazil and in other countries of the world. For Moreira and Monteiro (2012, p.3), prostitution is the ideal scenario for the consummation of gender violence. Since Brazilian society sees the activity of prostitutes as illicit and morally reprehensible, women are exposed to even greater dangers, given the neglect of the State and institutions. Like the vacant lots and corners described by the characters of Antares, the street environment makes them subject to "the arbitrary aggressions of the police, 
agents and customers", which involves insults, abuse, human trafficking, rape, theft; verbal humiliation and moral; in addition, many of these aggressions "are not registered in health services" (MOREIRA and MONTEIRO, 2012, pp. 3-4).

Like the character Erotildes, the pianist and music teacher Menandro Olinda is used by Veríssimo as a form of criticism of an authoritarian, conservative and fundamentalist ideology present not only in the utopian city of Antares, but in Brazil in which Veríssimo lived. The case of Professor Menandro deserves mention not only for involving musical art, but especially for his literary richeness and his critical potential in the context of the work:

The pianist stands up, trembling, heading for the stage, where he is received with rare applause. He returns to the piano. He looks to the backstage and there's his mother, who nods at him, trying to encourage him. A bright, cheerful Schubert's sonatina. He does it easily and that gives him a little courage. But now comes Appassionata! Menander turns his head in the direction of the audience and feels dizzy. Then he looks at his own hands already lodged on the keyboard [remembering immediately that traumatic scene that marked his childhood]. But that day when he had masturbated in the bedroom, he had forgotten to close the door, and his mother wore woolen slippers at home. The door suddenly opened. "My goodness! What are you doing, my son? How horrible! What a shame! What a sin! God will punish you, dry those fingers, paralyze those hands! "And he rolled on the bed, his sap squirting from his body in a rush of pleasure mixed with fright and shame. Her mother broke into a convulsive cry: "My son! My little boy I thought he was innocent and pure! Oh! How embarrassing! God will punish you!" He turned and knocked on the door. And he, Menander, burst into tears, thought of killing himself, running away from home... How could he have dared to face his mother again... the father? The public waits impatiently. Menander starts the Appassionata. However, he feels his hands are now paralyzed, his fingers do not obey his brain. He suddenly rises, knocking over the stool, and almost runs off the stage, and in the dressing room he begins to cry, to sob, and to say inconsistencies. Two days later, on the advice of the physician, his parents interned him in a sanatorium for mental illness, where he remained for three years (VERÍSSIMO, 2006, pp. 174-175).

This part of Veríssimo's book refers to a fundamentalist and authoritarian mentality present in Brazilian History (not only in the context addressed by the author, but in earlier periods and even today), which regards masturbation as a sin against the Christian divinity. The denial of the pleasures of the body and the conception of sex only as a means of reproduction refers to the times of medieval Europe, where the Catholic Church was a dominant institution (PEREIRA, 2014, pp. 34-35), but remains alive in the contemporaneity (PEREIRA, 2014, pp.86-89). We only have access to websites of conservative Christian groups to find stories and articles that "guide" young people and families about this controversial issue. In a (undated) text signed by Father Reinaldo Cazumbá on the site of a catholic group called Canção Nova, masturbation is labeled as a "disorderly act", an "egocentric and nar- 
cissistic" attitude, mean for "proliferation of promiscuity", a serious moral disorder "that can cause" moral and psychological harm "to those who practice it. Against this "sexual addiction," the only way would be a "Christian formation" and an incisive "pedagogical action" (CAZUMBÁ, 200-?).

On the Protestant side of Christianity, the Pastor and theologian Alberto Ronaldo Timm, a renowned intellectual of the Seventh-day Adventist Church, believes that the "masturbation addiction" opposes to "the high principles of moral and spiritual purity of Christianity," thus being a selfish act which, according to the laws of the Bible, should be "shared exclusively within the marriage relationship" (TIMM, 1998, p.29). Beyond the religious leaders' discourses, the results of Pereira's research (2014, pp. 86-89) show how such thought is recurring among young people, especially those of evangelical families.

Back to the incident that shook the calm and dystopian city in Rio Grande do Sul, the seven dead waited for the authorities' responses to the gravedigger strike, while they gathered for the final act in the bandstand. Positioned at a certain distance, given the unbearable smell of the corpses, the whole city gathers to watch that curious and scary scene. The perplexity of the audience not only involves the frightening presence of the deceased, but the content of their denunciations against local authorities, especially against Inocêncio Pigarço, the torturer delegate, Vivaldino Brazão, the mayor of the city, and the powerful colonel Vacariano. Through Dr. Cícero Branco's voice, the renowned and deceased lawyer (now a post mortem representative of the unburied, among whom was himself included), Veríssimo delineates one of the most emblematic scenes of the Incident, denouncing to the people of Antares what really happened in the basements and police stations while the official press and authorities distorted and tried to cover up the real happenings. Considering the year 1971, the date of publication of the book, this scene demonstrates the critical and combative stance of Veríssimo through his literary dystopia in the middle of the military dictatorship, as a clamor of denunciation to the Brazilian and Latin American people for the atrocities experienced in that truculent period:

One day in December, João Paz was arrested on the false charge of secretly training in our city a band of ten leftist guerrillas of which he was supposedly the chief. His arrest was carried out in the most irregular manner. João Paz was taken to the famous basement of our police station where the most brutal interrogations take place. Inocêncio Pigarço asked the prisoner questions, ordered him to name the ten other "members of the group." Johnny refused to do that because he did not know anything, because such a group does not exist in Antares! Inocêncio Pigarço handed the "subversive" to the care of his "specialist" in interrogations, the infamous Boquinha de Ouro... that must be somewhere in this square and hopefully he is listening to me. [...] I think everyone can see these round spots on the face and hands of João Paz... Because they were produced by burning cigarette butts, in the first phase of the interrogation... something light, let's say... just like a warming up... [...] Johnny stood strong... and did not say a name. Boquinha de Ouro asked: "Who are the other ten? Come on!" And the prisoner answered: "I don't know." The executioners then proceeded to the second phase of the interro- 
gation. Two brutes beat Johnny, punching and kicking him in the face, his stomach and his testicles... I beg your pardon, Puritans ladies and gentlemen, for using the word testicle, but I can assure you that the punches and kicks hurt more in this part of João Paz's anatomy than the word testicle can hurt in the delicate ears of your verbal morality. [...] Do you see this eye almost out of orbit? Asks Cícero Branco. It looks like a quail egg... yes, and that clotted blood that resembles dry ketchup ... If you'll excuse me for the bad taste of the metaphor, the eyelids and the skin around Johnny's eyes resemble a cabbage leaf purple. Keep this picture in mind to remember it at mealtimes forever. A quail egg on top of a leaf of purple cabbage. It is an excellent mnemonic and plastic process (sinister still-life) not to forget the cruelties of our police (VERÍSSIMO, 2006, pp.374-375)

Through the dead one, Barcelona, who during his life was a cobbler, defender of anarchism and a critic of the State and the bourgeoisie, Veríssimo makes clear his political position in the face of the inequalities of his time. When meeting with Pigarço, the corrupt and torturing delegate, Barcelona had said: "I am dead and rotten... [unlike you, who] are alive and more rotten than me. Rotten soul. Rotten heart. [...] I am a legitimate deceased and therefore I am free of capitalist society and its lackeys" (VERÍSSIMO, 2006, pp. 288-284). The outcome of the book - where the author insinuates that everything was a "collective delusion" of the population of that quiet city - is in fact a fierce criticism of the status quo of Brazilian society, that reinforces the need to preserve historical memory and subversive thought when it comes to the acts of manipulation of public opinion, oblivion and hypocrisy.

We can observe, as Bordini points out (1995, p. 13), that through the dystopia of Antares, the author "sets the dead to teach the living." In the words of Santos $(2014$, p. 358), Veríssimo denounces "all forms of violence and arbitrariness committed against human beings in any part of the world" (SANTOS, 2014, p.358). His novel, written at the height of the patriotism of the Brazilian military dictatorship, would include, above all, a political militancy of denunciation and search for social changes (SANTOS, 2014, p.334), a "bloody satire against the military regime, which the author "faced with the weapons of literature" (CANDIDO, 2001, pp. 16-17 apud SANTOS, 2014, p.358).

\section{FINAL CONSIDERATIONS}

As we have observed through the present article, when it comes to literature, dystopia represents anti-utopia, a negative utopia where its members are submitted to states of authoritarian, restrictive and controlling aspect. This dystopic universe was widely explored by the cinema, as in the classic Blade Runner (1982), Matrix (1999), Mad Max (1979), A Clockwork Orange (1972), and adaptations of literary works for the movies and series, such as Brave New World (1932) by Aldous Huxley (1894-1963), The handmaid's Tale (1985) by Margaret Atwood (n.1939), Fahrenheit 451 (1953) by Ray Bradbury (1920-2012), 1984 (1949) by Gorge Orwell (1903-1950), as well as Incident in Antares, that was transformed into series exhibited in 1994 and later adapted to a film. 
Broadly speaking, through dystopian societies, the authors criticized totalitarianism, social control through the mass media, and denounced the relations marked by violence, individualism, competition, techno-scientific domination, greed, by political corruption, by the mastery of cultural industry, instrumental rationality and capitalist exploitation. Addressing Brazilian society, we consider Érico Veríssimo's dystopia as a landmark in the History of literature, both in the national and Latin American context, since many of the authoritarian elements presented by the author were present in the military dictatorships of several countries of America Latina through the 20th century.

Through his seven unburied dead, Veríssimo gave life (or death?) to a dystopian novel capable of expressing the critical and anti-authoritarian political position of a generation that, in the wake of repression and torture legalized through Institutional Act No. $5^{5}$ , he called for freedom, justice and democracy. Almost fifty years after the publication of its first edition, the anti-authoritarian critique of the dystopic Antares remains prevalent, since many forms of repression and violence are present in several cities through the country, with the main victims being women, homosexuals, black people, indigenous peoples, suburbanites and workers. Thus, in a context where democracy and human rights are challenged by conservative discourses, defenders of authoritarianism and dictatorial regimes, dystopian societies are configured, as Veríssimo has shown, as an alert and a powerful critique of the reality that surrounds us.

\section{REFERENCES}

ADORNO, T.W. Educação e Emancipação. Tradução Wolfgang Leo Maar. 2a ed. Rio de Janeiro/São Paulo: Editora Paz e Terra S.A. 2000.

ADORNO, T.W. Teoria da Semiformação. In: PUCCI, ZUIN E LASTÓRIA (orgs). Teoria Crítica e inconformismo: novas perspectivas de pesquisa. Campinas-SP: Autores Associados, 2010. pp.7-40.

BAUDELAIRE, C. Sobre Los Caprichos de Goya. In GLEDINNING, N. Goya y sus críticos. Madrid: Ediciones Taurus, 1982. pp-302-311.

BORDINI, M. da G. Criação literária em Erico Verissimo. Porto Alegre: LPM; EDIPUCRS, 1995.

CANDIDO, A. Entrevista com Antônio Cândido. In: PESAVENTO, S. et al. (Org.). Erico Verissimo: o romance da história. São Paulo: Nova Alexandria, 2011.

CAZUMBÁ, R. Ato desordenado: Por que a masturbação é pecado? Portal da Comunidade Canção Nova, 200-?. Disponível em: https://formacao.cancaonova.com/afetividade-e-sexualidade/

5 The Institutional Act Number Five (AI-5) was the fifth of seventeen major decrees issued by the military dictatorship in the years following the 1964 coup d'état in Brazil. Institutional Acts were the highest form of legislation during the military regime, given that they overruled even the highly authoritarian Constitution, and were enforced without the possibility of judicial review. AI-5, the most infamous of all Institutional Acts, was issued by President Artur da Costa e Silva (1899-1969) on December 13th, 1968. It resulted in the forfeiture of mandates, interventions ordered by the President in municipalities and states and also in the suspension of any constitutional guarantees which eventually resulted in the institutionalization of the torture commonly used as a tool by the State. 
dependencia-sexual/por-que-a-masturbacao-e-pecado/. Acesso em 04/01/2019.

COELHO NETTO, J.T. O que é utopia. São Paulo: Brasiliense, 1985.

FAUSTO, B. História do Brasil. 13ª ed. São Paulo: Editora da Universidade de São Paulo, 2008.

GUDIOL, J. Goya. España: Ediciones Polígrafa, 2008.

MOREIRA, I.C.C.; MONTEIRO, C.F.S. A violência no cotidiano da prostituição: invisibilidades e ambiguidades. Revista Latino Americana de Enfermagem. set-out.2012. Disponível em http://www. scielo.br/pdf/rlae/v20n5/pt_18.pdf. Acesso em 04/01/2019.

PEREIRA, P. C. Educação sexual familiar e religiosidade nas concepções sobre masturbação de jovens evangélicos. Dissertação (mestrado) - Universidade Estadual Paulista Júlio de Mesquita Filho, Faculdade de Ciencias e Letras (Campus de Araraquara), 2014.

PINTO, M.C. Prefácio de Fahrenheit 451. In BRADBURY, R. Fahrenheit 451: a temperatura na qual o papel do livro pega fogo e queima; trad. Cid Knipel. $7^{\text {a }}$ reimpressão. São Paulo: Editora Globo, 2009. pp.13-20.

PLATÃO. A República. 2a Ed., São Paulo: Edipro, 2010a.

RODRIGUES, S.C. No labirinto do fantástico. Babilônia: Revista Lusófona de Línguas, Culturas e Tradução. [S.1.], n. 1, dec. 2010. pp.95-102. Disponível em: http://revistas.ulusofona.pt/index.php/ babilonia/article/view/1776. Acesso em: 10 mar. 2019.

SANTOS, D. O projeto literário de Érico Veríssimo. Revista Estudos de literatura brasileira contemporânea, n. 44, p. 331-363, jul./dez. 2014. Disponível em: http://www.scielo.br/pdf/elbc/n44/ a17n44.pdf. Acesso em 10/03/2019.

TIMM, A.R. Revista Sinais dos Tempos. Setembro de 1998, p. 29. In: A masturbação é pecado? Portal Biblia. 11 de abril de 2012. Disponível em: http://biblia.com.br/perguntas-biblicas/sexo/a-masturbacaoe-pecado/. Acesso em 04/01/2019.

VERÍSSIMO, E. Incidente em Antares. Prefácio de Maria da Glória Bordini. $1^{a}$ ed. Companhia de Bolso. 13ª reimpressão. São Paulo: Companhia das Letras, 2006. 


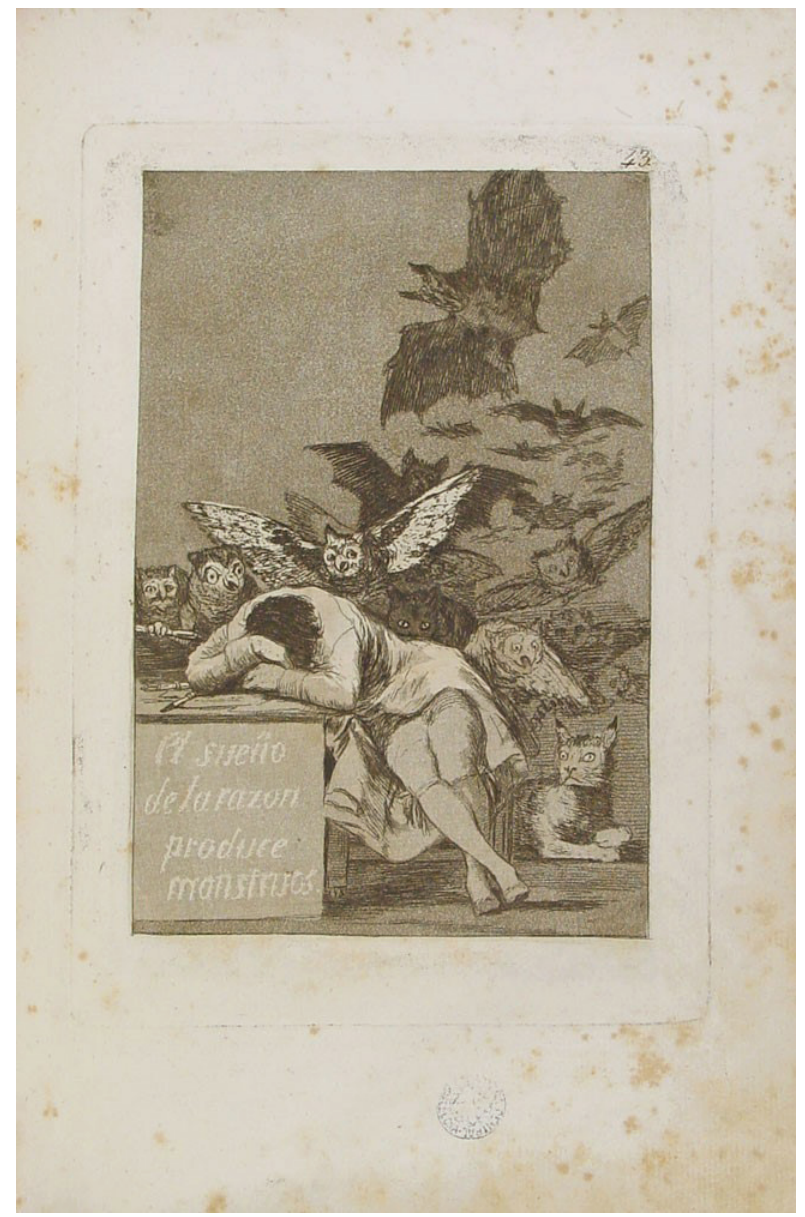

Capricho ${ }^{\circ}$ 43: El sueño de la razón produce monstruos (1799). Serie Los Caprichos. Francisco José de Goya y Lucientes (1746-1828) ${ }^{6}$.

6 Source: Biblioteca Virtual Miguel de Cervantes. Disponível em: http://www.cervantesvirtual.com/servlet/SirveObras/01593307546704995222257/ima0084.htm. Acesso em 10/03/2019. 
